\title{
De farmacoloog
}

Citation for published version (APA):

Struijker Boudier, H. A. J. (2017). De farmacoloog: zondebok of precisie-heelmeester? Maastricht University. https://doi.org/10.26481/spe.20171103hsb

Document status and date:

Published: 03/11/2017

DOI:

10.26481/spe.20171103hsb

Document Version:

Publisher's PDF, also known as Version of record

\section{Please check the document version of this publication:}

- A submitted manuscript is the version of the article upon submission and before peer-review. There can be important differences between the submitted version and the official published version of record.

People interested in the research are advised to contact the author for the final version of the publication, or visit the DOI to the publisher's website.

- The final author version and the galley proof are versions of the publication after peer review.

- The final published version features the final layout of the paper including the volume, issue and page numbers.

Link to publication

\footnotetext{
General rights rights.

- You may freely distribute the URL identifying the publication in the public portal. please follow below link for the End User Agreement:

www.umlib.nl/taverne-license

Take down policy

If you believe that this document breaches copyright please contact us at:

repository@maastrichtuniversity.nl

providing details and we will investigate your claim.
}

Copyright and moral rights for the publications made accessible in the public portal are retained by the authors and/or other copyright owners and it is a condition of accessing publications that users recognise and abide by the legal requirements associated with these

- Users may download and print one copy of any publication from the public portal for the purpose of private study or research.

- You may not further distribute the material or use it for any profit-making activity or commercial gain

If the publication is distributed under the terms of Article $25 \mathrm{fa}$ of the Dutch Copyright Act, indicated by the "Taverne" license above, 
Prof.dr. H.A.J. Struijker Boudier Faculty of Health, Medicine and Life Sciences

De farmacoloog: zondebok of precisie-heelmeester? 
Geachte rector, waarde collega's, geachte aanwezigen,

Een tijdje geleden las ik de prachtige biografie van Goethe, geschreven door Rüdiger Safranski (1; figuur 1). Goethe: de alleskunner: diplomaat, dichter, wetenschapper, filosoof, minnaar. Alles ging Goethe gemakkelijk af, behalve één ding. Het lukte hem alsmaar niet om zijn opus magnum - de Faust - te voltooien. M eer dan 40 jaar werkte hij aan dit boek. Op hoge leeftijd lukte het hem uiteindelijk en Safranski eindigt zijn biografie op dat moment met de zinsnede: "toen was Goethe eindelijk de mens geworden die hij was".

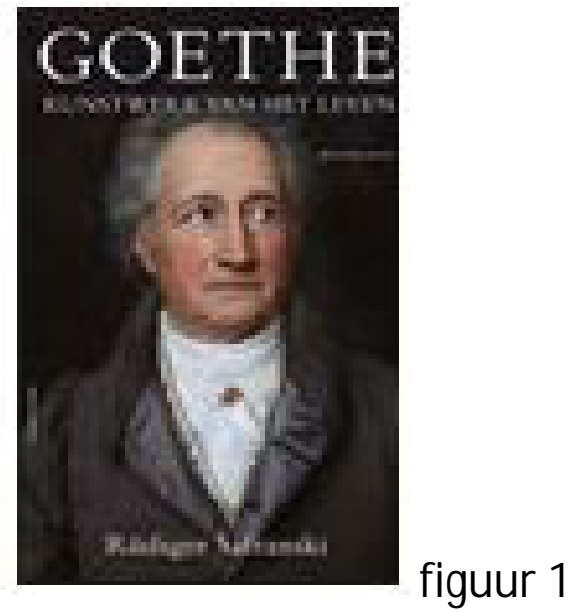

"Worden wie je bent" lijkt een actueel thema in deze tijd van zoekende identiteiten. De NRC wijdde begin dit jaar een wekenlange rubriek onder de titel "Worden wie je bent" en er worden zelfs symposia gehouden door oudpromovendi onder de titel "Becoming who you are". Zo actueel is dit thema echter niet. Dante's Divina Commedia uit 1300 is een indrukwekkend reisverslag van de mens die zichzelf leert kennen. En zelfs al in de $5^{\mathrm{e}}$ eeuw introduceerde de kerkvader Augustinus het "Amo, volo ut sis" in het katholieke doopritueel. Door deze uitspraak zeggen de ouders de dopeling toe dat ze van hem of haar zullen houden en hem of haar toewensen dat hij of zij zal worden wie hij is. Later werd het "Amo, volo ut sis" een hoofdthema in het werk van belangrijke filosofen zoals Friedrich Nietzsche en Hannah Ahrendt.

Ook de afscheidsrede is voor menig hoogleraar een moment om zich af te vragen wie hij of zij is geworden. Overigens herhaal ik vanaf nu niet meer steeds "hij of zij". Als ik "hij" zeg, bedoel ik ook "zij" en ieder die zich daartussen of daarnaast bevindt. Veel professoren kijken in hun afscheidsrede 
terug op hun wetenschappelijke leven en brengen daarin een logische lijn aan hoe ze van A naar Zzijn gekomen. Ik geloof, eerlijk gezegd, niet in zo'n lineair verloop van het leven. Ik ben meer een aanhanger van de Argentijnse dichter en essayist Borges (figuur 2), die in zijn essay "Het onbeduidende van de persoonlijkheid" stelt dat de stappen die een mens zet, van zijn geboorte tot aan zijn dood, een onbegrijpelijke figuur in de tijd beschrijven (2).

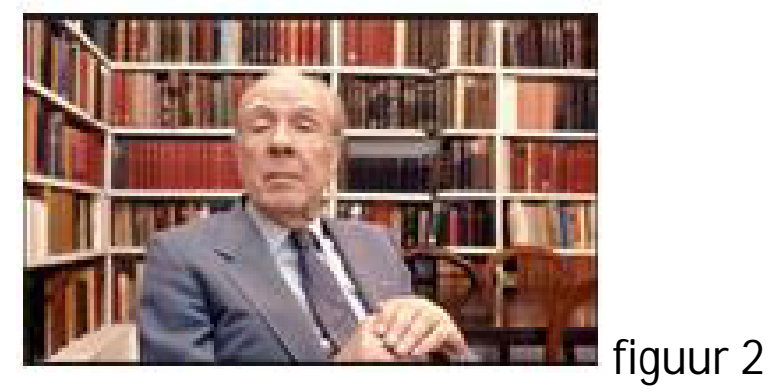

Ook hedendaagse denkers als Yuval Harari (3) en Pankaj M ishra (4) beschrijven de lineaire ondeelbare persoonlijkheid als een laatste stuiptrekking van de verlichting, c.q. de moderniteit. En ook onze rector magnificus vatte dit belang van de intrapersoonlijke diversiteit recent nog eens heel helder samen (figuur 3).

"Je moet geen beleid maken op één aspect van het mens-zijn.

Je bent het één en het ander en nog weer iets anders, tegelijkertijd."

Rianne Letschert

De Observant 21 sept. 2017

figuur 3

Naar mijn mening wordt de levenslijn vooral bepaald door een aantal, vaak toevallige, ontmoetingen met mensen of culturen. Ik wil $u$ in deze afscheidsrede meenemen langs een aantal ontmoetingen die een beslissende rol in mijn leven speelden. Vooral wil ik mijn dankbaarheid voor die ontmoetingen tot uitdrukking brengen. Om te vermijden dat deze rede al te zeer een ego-document wordt, heb ik als meta-thema een andere identiteitsvraag verweven, namelijk die van de farmacoloog: is hij een zondebok of een precisie-heelmeester?

M ijn persoonlijke verhaal begint met de eerste ontmoeting zoals vrijwel iedereen die meemaakt, namelijk het gezin waarin hij wordt geboren. In mijn geval was dat in 1950 als nakomertje in een gezin dat weliswaar compleet, maar getraumatiseerd terug gekomen was uit verschillende Japanse 
interneringskampen in het toenmalig Nederlands Indië. Veel tijd voor rouw, rust en reflectie was er niet in de jaren 50 , en zoals het betaamt in een gezin met 2 onderwijzers als ouders moest er hard gewerkt en gestudeerd worden. Een paar van mijn oudere broers kozen de gymnasium alpha richting en werden later neerlandicus en filosoof. Voor mij werd het HBS-b en mede onder invloed van de inspirerende biologie leraar mijnheer Oude Vrielink een gecombineerde universitaire studie scheikunde en biologie.

Ik deed bijvak stages in de biochemie bij de fameuze Hans Bloemendal en in de dierpsychologie, waarin ik goudvissen trainde door een hoepeltje te zwemmen en apen observeerde in hun natuurlijke omgeving. Vooral die laatste stage is mij later goed van pas gekomen in mijn werk op de apenrots van de universiteit. Ik vond mijn bestemming in de farmacologie door een toevallige ontmoeting met de jonge hoogleraar Jacques van Rossum (figuur 4), een briljant en absoluut onconventionele man, die ik zeer dankbaar ben voor de passie die hij toonde voor het vak farmacologie. Het onderwerp van mijn hoofdvak stage, en niet veel later ook van mijn promotieonderzoek gaf hij mij op in de lift tussen de le en $3^{\mathrm{e}}$ verdieping van het farmacologisch instituut in Nijmegen. M et weemoed denk ik terug aan die tijd, nu ieder promotieonderzoek van te voren beschreven moet worden in een aanvraag van 20 pagina's met even veel goedkeuringsverklaringen en wij promovendi mediatraining geven en duur betaalde consultants inschakelen als ze een VENI beurs willen aanvragen.

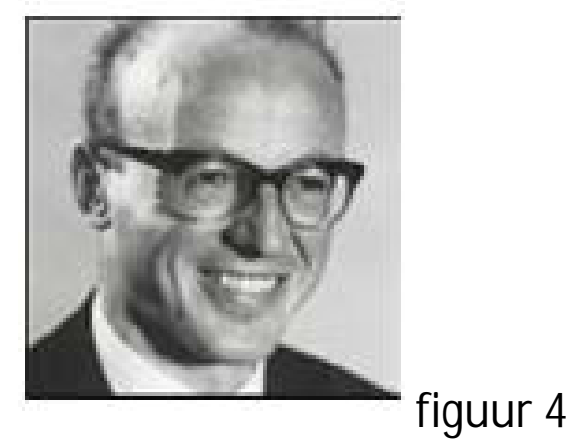

Voor mijn promotieonderzoek kreeg ik de beschikking over een aantal pas ontworpen antipsychotica van van Rossum's goede vriend Paul Janssen, directeur van het bedrijf Janssen Farmaceutica, en zeker een van de allergrootste farmacologen van de vorige eeuw. Het was de bedoeling dat ik ging onderzoeken hoe deze antipsychotica de dopamine neurotransmissie in de 
hersens van de slak Helix aspersa beïnvloeden. Leg dat thuis maar eens uit: de werking van antipsychotica in slakkenhersens. Toch deden we een mooie ontdekking: het bleek dat dopamine een deel van de slakkenneuronen activeerde en een ander deel juist remde. Wij waren daarmee de eersten die ver vóór de tijd van receptor clonering het bestaan van 2 typen dopamine receptoren aantoonden, wat later de basis werd voor de ontwikkeling van nieuwe en betere antipsychotica (5).

Aangezien slakkenonderzoek seizoensgebonden is had ik tijd over om me te verdiepen in een van de andere hobby's van Jacques van Rossum, namelijk het werkingsmechanisme van bloeddrukverlagende stoffen. Wederom had Van Rossum door zijn goede contacten met de industrie de beschikking over een zojuist ontwikkelde bloeddrukverlager: clonidine, een stof die eigenlijk was ontwikkeld als toevoeging aan scheerzeep om kapot geschoren bloedvaatjes te sluiten, maar die in proefpersonen onverwacht bloeddrukdaling bleek te veroorzaken. M ijn latere loopbaan als onderzoeker van bloeddrukverlagende geneesmiddelen begon dus met een toevalstreffer, vergelijkbaar met Viagra dat bedoeld was als bloeddrukverlager, maar onverwacht een door velen - en nu laat ik in het midden of het hij of zij is - hoogst gewaardeerde bijwerking bleek te hebben.

M ijn Nijmeegse tijd eindigde in 1975 door een onverwachte brief uit Maastricht van de onvolprezen Sjeng Tans. Ik was tot dan toe pas 1 keer - in 1967 - in $M$ aastricht geweest om als onderdeel van mijn ontgroening bij de studentenvereniging Diogenes op het Vrijthof te demonstreren voor een universiteit in M aastricht. $U$ ziet hier 2 afbeeldingen uit De Nieuwe Limburger van 2 september 1967 die dit evenement tonen (figuren 5 en 6).
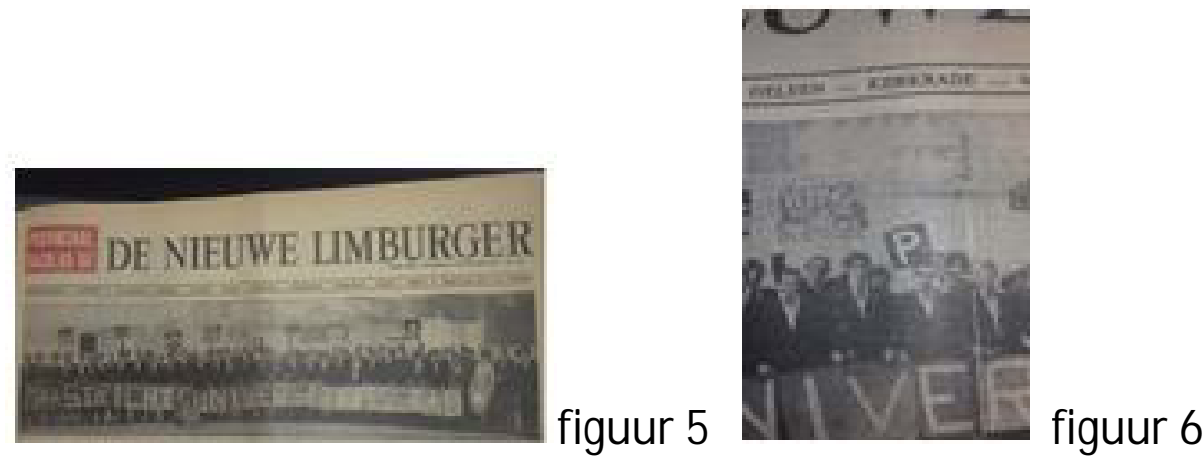
Tans' uitnodiging betrof het tezamen met Karl-Heinz Rahn oprichten van een capaciteitsgroep farmacologie in de $8^{\mathrm{e}}$ medische faculteit. Tussen Heinz Rahn, die als hoogleraar klinische farmacologie de eerste voorzitter van de capaciteitsgroep werd en mij klikte het direct. Na onze gesprekken met de voorbereidingscommissie in het Jezuïeten klooster in de Tongersestraat maakten wij lange wandelingen door het toen nog wetenschappelijk maagdelijk $M$ aastricht. Die wandelingen, waarin wij besloten dat geneesmiddelbehandeling van hoge bloeddruk ons gezamenlijk research onderwerp zou worden, eindigden meestal in een klein Indonesisch restaurant in de Tongersestraat. Niet veel later begonnen op die plek George en Fien Hoeberechs hun fameuze café de Oude Klok, de plek waar M aastricht definitief haar maagdelijkheid- althans de wetenschappelijke- verloor.

De jonge $8^{e}$ medische faculteit was zo genereus om mij, alvorens in Maastricht te beginnen één jaar als post-doc naar Jackson, $M$ ississippi te laten gaan om daar bij de beroemde fysioloog Arthur Guyton de details van de bloeddruk regulatie te leren. Arthur Guyton was wetenschappelijk zijn tijd ver vooruit, want al in 1972 publiceerde hij een op een complex computermodel gebaseerde systeem biologische analyse van het hart-vaatstelsel (6).

In M ississippi ontmoette ik in 1976 de persoon die daarna 40 jaar lang op vele manieren een grote invloed op mijn leven heeft gehad: John Urquhart (figuur 7). John, breed geïnteresseerd intellectueel, opgeleid als chirurg op Harvard, succesvol biotechnologisch onderzoeker en later oprichter van één van de eerste Californische biotech bedrijven: ALZA. Ook hier was een onmiddellijke klik en onze ruim 40-jarige vriendschap heeft geleid tot talrijke gezamenlijke publicaties over heel verschillende onderwerpen, waaronder een in meerdere talen verschenen boek over risico analyses in technologische maatschappijen (7).

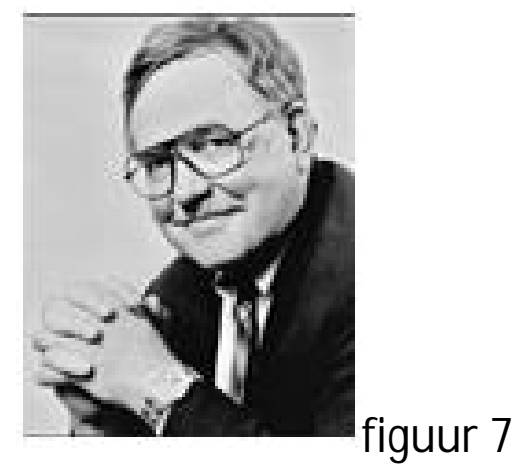


In 1977 zaten mijn vormende jaren erop en begon het serieuze leven in $M$ aastricht. $M$ et Jos Smits als zeer begaafde experimentator begonnen wij een laboratorium voor het onderzoek naar oorzaken en behandeling van hoge bloeddruk. Die keuze bleek om meerdere redenen een gelukkige te zijn. Op de eerste plaats waren de jaren 70 de start van de ontwikkeling van de moderne generatie antihypertensiva (figuur 8). In ons onderzoek concentreerden wij ons op de ontrafeling van het werkingsmechanismen van diverse antihypertensiva.

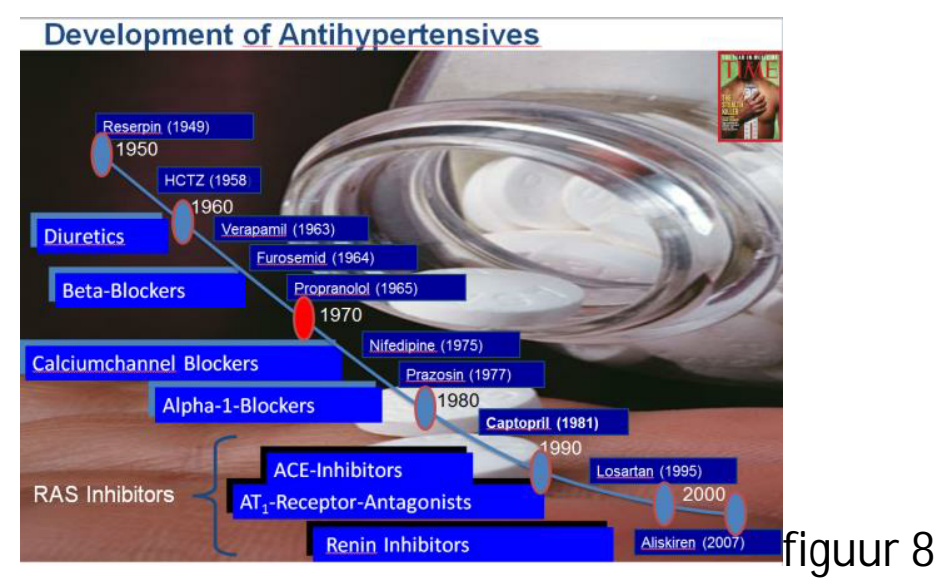

De introductie van de nieuwe generatie antihypertensiva in de laatste 40 jaar heeft tot grote successen geleid in het bestrijden van hart- en vaatziekten. M ede door de effectieve behandeling van hoge bloeddruk is de vroegtijdige sterfte aan hart- en vaatziekten in West-Europa, Noord Amerika, Japan en Australië spectaculair afgenomen en de levensverwachting in de laatste decennia met circa 10 jaar toegenomen met bovendien een aanzienlijke verbetering van de levenskwaliteit door de sterke afname van hersenbloedingen en hartinfarcten, die mede het gevolg zijn van nietbehandelde hoge bloeddruk (8). Helaas geldt deze afname in hart- en vaatziekten niet voor andere delen van de wereld, m.n. niet voor zuid-oost Azië en Latijns-Amerika. De laatste jaren heb ik veel door die werelddelen gereisd om een effectieve aanpak van hun cardiovasculaire epidemie te bespreken.

Ook op talrijke andere gebieden van de gezondheidszorg heeft de farmacologie van de laatste 40 jaren belangrijk bijgedragen tot de kwaliteit van leven (figuur 9). Ik noem hier bijvoorbeeld de pijnbestrijding, de behandeling van reuma, de effectieve verlaging van te hoog cholesterol, de bestrijding van diabetes en astma, de behandeling van infectieziekten en in het bijzonder aids, 20 jaar geleden nog een absoluut dodelijke ziekte die nu goed behandeld kan worden 
met antivirale geneesmiddelen, de psychofarmaca voor diverse psychiatrische ziekten - hoewel met nuanceringen waarop ik later in deze rede nog uitvoerig terugkom- en niet op de laatste plaats de anticonceptiepil, een niet te onderschatten factor in de vrouwenemancipatie. Al met al waren farmacologen in de laatste 35 jaar goed voor minstens 8 Nobelprijzen in de geneeskunde (figuur 10).
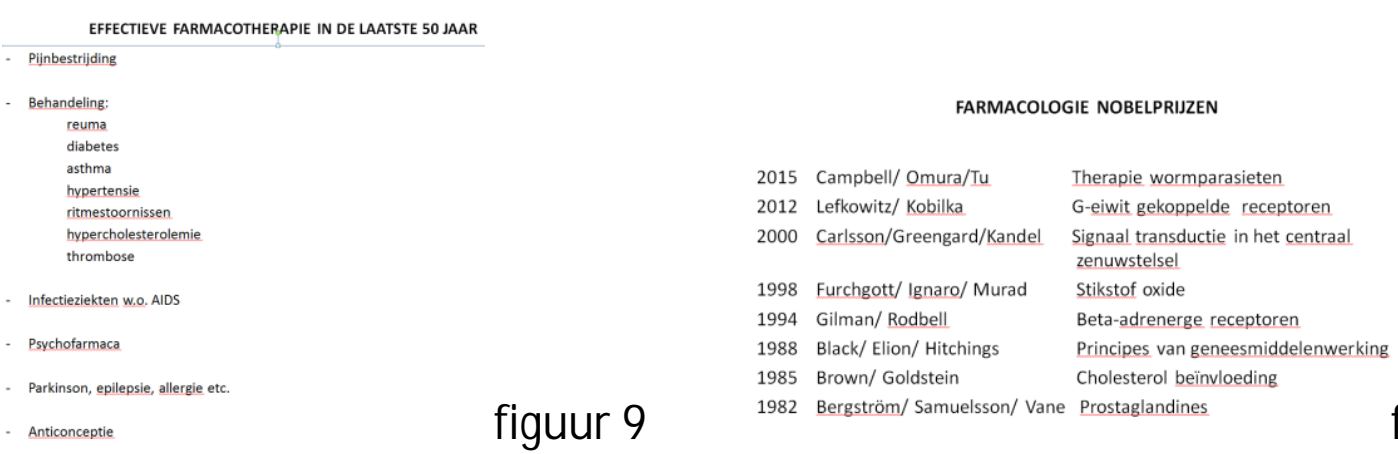

figuur 10

Ondanks deze enorme successen staan geneesmiddelen vaak in een kwaad daglicht. Als voorbeeld toon ik u een filmpje (figuur 11), dat circuleert op de internationale informatierioolbuis: het internet.

\section{- https://www.youtube.com/watch?v=Lp3pFjKo} $\underline{\mathrm{zl} 8}$

figuur 11

Dit filmpje - dat nog een tijdje doorgaat - somt alle ellende op die pillen kunnen veroorzaken. Inderdaad kunnen geneesmiddelen voorbij schieten aan hun doel en ongewenste effecten veroorzaken. Heel vaak zijn die ongewenste effecten het gevolg van onjuist gebruik van de geneesmiddelen. Zo slikt minder dan de helft van hoge bloeddruk patiënten hun medicatie volgens voorschrift (9). Een illustratief voorbeeld hiervan is de volgende waar gebeurde casus: een oudere dame wier plaspillen op donderdag op waren besloot het bezoek aan de huisarts-apotheker voor een nieuw recept uit te stellen tot de maandag erop. Op zondagavond moest ze plotseling wegens acuut hartfalen op de intensive care worden opgenomen. Twee weken later en 10.000 euro armer verliet ze het ziekenhuis als gevolg van het niet slikken van plaspillen ā raison van enkele centen. Uit een recent onderzoek van Anne Leendertse uit Utrecht blijkt dat in Nederland ongeveer $6 \%$ van alle niet-geplande ziekenhuisopnames gerelateerd was aan een geneesmiddel, waarbij ongeveer de helft werd veroorzaakt door de foute wijze waarop mensen het geneesmiddel gebruikten 
(10). Betere bewaking van het geneesmiddelgebruik zou niet alleen veel patiëntenleed kunnen voorkomen, maar alleen al in Nederland meer dan 100 miljoen euro per jaar aan kosten kunnen besparen.

Wat het filmpje ook toont is de aversie tegen geneesmiddelen waarbij de farmacoloog verantwoordelijk wordt gehouden voor de verschaffing van giftige "chemische troep". Dit brengt mij op de dubbele betekenis van het Griekse woord "pharmacos" waarvan de naam van farmacoloog is afgeleid. In het oudGrieks betekende "pharmacos" zowel de brenger van heil als de zondebok. De pharmacos was in de Griekse cultuur zowel de weldoener die genezing bracht als de boosdoener die over de krachten van het kwaad beschikte. In een jaarlijks ritueel werd uit een Griekse stad de zondebok buiten de muren van de stad gedood om op die manier de stad te zuiveren van het kwaad. De beroemdste Griekse zondebok was Socrates die door Athene ter dood werd veroordeeld wegens zijn bedreigende dialogen. Als vertegenwoordiger van het kwaad werd Socrates gedood om Athene rein te houden.

De Franse filosofen Jacques Derrida (11) en René Girard (12; figuur 12) hebben de dubbele betekenis van de pharmacos uitvoerig onderzocht. In zijn diepgravende studie Le bouc émissaire- de zondebok- geeft de Franse filosoof René Girard de volgende verklaring. De pharmacos bracht niet alleen heil maar doorbrak ook de orde in de gemeenschap. Volgens de zogenaamde mimetische theorie van Girard ontwikkelen mensen hun begeerten doordat ze anderen nabootsen. Zij imiteren elkaar in hun verlangen leidend tot een geordende maar ongedifferentieerde massa. Socrates, of later Jezus in de christelijke traditie, bracht niet alleen heil, maar bedreigde ook de bestaande maatschappelijke ongedifferentieerde orde. Socrates bediende zich van een nieuwe taal: de dialoog en sprak daarmee niet langer de taal van zijn stadsgenoten. De andere beroemde zondebok - Jezus - was een bedreiger van de toendertijd gevestigde Joodse orde met zijn heilsboodschap.

Jacques Derrida: Plato's pharmacy. Tel quel no.

32 et 33,1968

René Girard: Le bouc-émissaire / De zondebok Grasset, Paris 1982

figuur 12

Een meer recent voorbeeld van het creëren van een zondebok was de wijze waarop Hitler in het fascistische Duitsland eerst een ongedifferentieerde massa 
creëerde en die vervolgens aanzette tot haat en uiteindelijk vernietiging van de joden als zondebok ten einde het arische ras te zuiveren. In de $19^{\mathrm{e}}$ eeuwse medische wereld is een bekend voorbeeld van een zondebok Ignace Semmelweis, zoals de Franse arts en schrijver Louis Destouches, later beter bekend onder zijn schrijversnaam Céline - schrijver van zowel antisemitische pamfletten als indrukwekkende romans - in zijn korte maar briljante proefschrift aan de Parijse universiteit omschreef (13). Semmelweis werd door de Weense medische stand uitgestoten wegens zijn opzienbarende - en later als juist bewezen- hypothese over de oorzaak van de kraamvrouwenkoorts ten gevolge van slechte hygiëne van de artsen. Ik zou niet zover willen gaan de moderne farmacoloog/pharmacos op één lijn te stellen met Socrates, Jezus of Semmelweis, maar sommige elementen van Girard's theorie zijn zeker van toepassing op de perceptie van ons vak.

Terug naar M aastricht. Ik zei eerder dat er meerdere redenen waren waarom de keuze van het onderzoek naar de behandeling van hoge bloeddruk en harten vaatziekten een gelukkige was. De tweede reden is dat die keuze nauw aansloot bij de interesses van de collegae Wellens, Hemker en Reneman. Onder de bezielende leiding van Rob Reneman leidde dit al in de vroege jaren 80 tot een bundeling van het Maastrichtse hart- en vaatziekten onderzoek en in 1987 tot de vorming van in Nederland een van de allereerste universitaire onderzoeksinstituten, het CARIM . Rob was daarbij niet alleen een excellent onderzoeksmanager, die nooit zijn eigenbelang voorop stelde, ook inhoudelijk hebben wij in de loop der jaren heel veel samengewerkt met talrijke gezamenlijke publicaties en promoties op het gebied van de micro- en macrocirculatie. Ik kom daar nog op terug.

M idden jaren 80 deed nog een andere persoon haar intrede in mijn leven en dat was Ardi, mijn echtgenote. Ik noem en bedank haar nu al en niet op het traditionele einde van deze rede, waarin de partner meestal wordt bedankt voor al haar geduld tijdens de vele uren die de professor op inspannende buitenlandse congressen doorbracht. Op de eerste plaats is Ardi niet het type om geduldig op mijn thuiskomst te wachten: zij heeft haar geheel eigen dynamiek. Op de tweede- en nog belangrijker- plaats heeft zij niet alleen in ons gezinsleven maar ook in mijn professionele keuzes een belangrijke rol gespeeld. Dat begon al meteen toen wij elkaar leerden kennen. In die periode overwoog 
ik sterk om een aanbod van ALZA, het bedrijf van John Urquhart, te accepteren om in Californië research directeur te worden. We zijn toen in korte tijd 2 keer naar San Francisco gevlogen en Ardi was onmiddellijk zeer enthousiast over dit vooruitzicht. Haar intuïtie bleek uitstekend, want een paar jaar later werd ALZA als een van de eerste Silicon Valley biotech bedrijven voor een gigantisch bedrag verkocht en werd onder andere de research directeur multi-miljonair.

Een gemist miljonairsleven in Californië, dat zou Borges zijn bevallen. Ik luisterde toen helaas nog niet naar haar intuïtie en besloot om in Maastricht te blijven vanwege het aantrekkelijke research klimaat en omdat Heinz Rahn een positie als hoogleraar in M ünster had aanvaard en ik onze capaciteitsgroep nog niet voldoende volwassen vond. Een paar jaar later was Ardi's invloed wel doorslaggevend. Ik kreeg begin jaren 90 van de faculteit de mogelijkheid een sabbatical jaar op te nemen. Ik koos toen voor Frankrijk vanwege de nauwe banden van Ardi via haar broer en diens Franse schoonfamilie. Dat was de start van een lang zowel wetenschappelijk als privé Frans avontuur dat recent uitmondde in Ardi's allerbeste vondst: het kunstcentrum La Borie vlakbij Limoges (figuur 13). Het voert te ver om $U$ alle plannen voor het emeritaat tijdperk te schetsen, maar ik kan U verzekeren dat La Borie een zeldzaam aangename plek is.

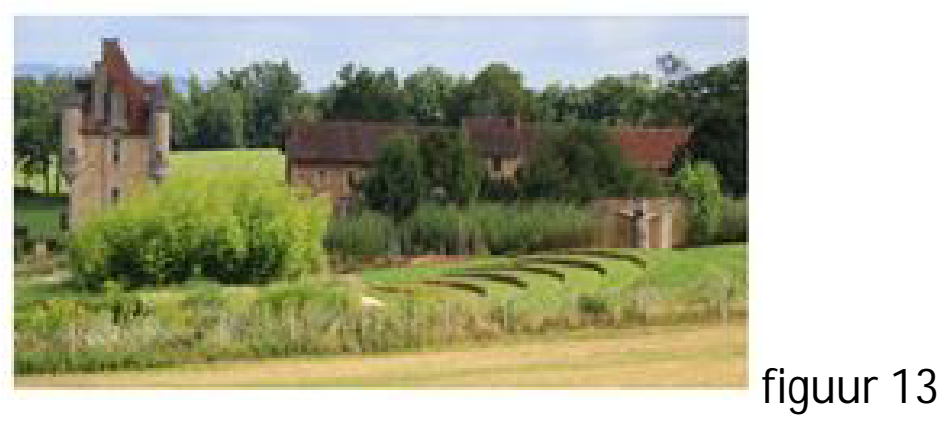

Het sabbatical in 1991 in Parijs in het Hôpital Lariboisière bracht mij in contact met de 4 musketiers van het Franse vaatonderzoek, Michel Safar, Stéphane Laurent, Bernard Lévy en Alain Tedgui (figuur 14). Als M aastrichtse D'Artagnan voelde ik mij onmiddellijk thuis en dit leidde niet alleen tot warme vriendschappen, maar ook een grote reeks gezamenlijke publicaties op het gebied van het arteriële stijfheidsonderzoek, een gebied dat in Maastricht al was ontwikkeld door Rob Reneman en Arnold Hoeks. Het doet mij veel genoegen dat die onderzoekslijn ook nu nog door Coen Stehouwer, Casper 
Schalkwijk, Bram Kroon, Koen Reesink en Leon Schurgers wordt voortgezet. In dat onderzoek is overtuigend komen vast te staan dat vaatstijfheid een belangrijke bloeddruk-onafhankelijke risicofactor is voor hart- en vaatziekten. Wat tot nu toe nog niet is gelukt is het vinden van een adequate farmacologische behandeling van toegenomen vaatstijfheid. In Parijs zullen we in februari 2018 een conferentie houden met onze Franse vrienden om de farmacologische opties goed op een rij te zetten.

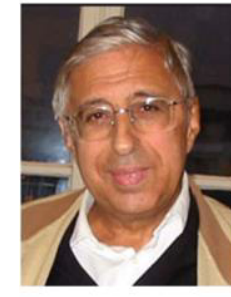

Michel Safar

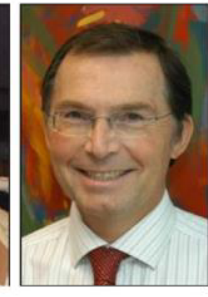

Stéphane Laurent Bernard Lévy

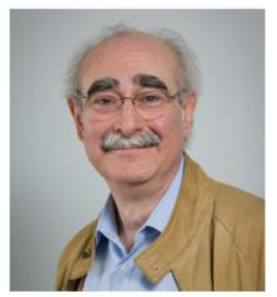

Alain Tedgui

les 4 mousquetaires vasculaires

figuur 14

Het vaatonderzoek van de laatste jaren bracht mij in contact met Jan Staessen uit Leuven, de laatste reus op wiens schouders ik al een aantal jaren om me heen heb mogen kijken. Jan is wereldwijd zonder twijfel één van de beste en invloedrijkste cardiovasculaire epidemiologen. Ik heb het als een groot voorrecht beschouwd dat hij al jaren, evenals John Urquhart in het verleden, een positie als onbezoldigd hoogleraar in M aastricht heeft geaccepteerd. Niet alleen ikzelf, maar ook de M aastrichtse Universiteit heeft enorm veel baat gehad bij de inbreng van deze collegae. De samenwerking met Jan Staessen heeft zich gericht op uitvoerige geno- en fenotypen van het hart-vaatstelsel in een grote bevolkingsgroep die Jan al jaren in België vervolgt. Wij proberen daarbij in die bevolkingsgroep zoveel mogelijk individuele genetische en vaatwandeigenschappen in kaart te brengen (14).

Dit brengt mij op het gebied van de precisie-geneeskunde, of - zoals het in het Engels wordt genoemd - de "personalized medicine", waaraan ik het tweede deel van deze rede wil besteden. M aar allereerst een tweede muzikaal intermezzo (figuur 15). 
https://www.youtube.com/watch?v=E

JaUDzhBFr4\&feature=youtu.be

figuur 15

U hoorde Simone Keres met een deel van de aria "Chi non sente" uit de opera M erope van Ricardo Broschi. Ricardo Broschi heeft deze aria waarschijnlijk gecomponeerd voor zijn broer Carlo Broschi, beter bekend als Farinelli. Farinelli was in zijn tijd een wereldberoemde castraatzanger. Hij trad al vanaf jonge leeftijd op in alle operahuizen en Koninklijke hoven in Europa, totdat hij in 1737 het hof van koning Filips V en koningin Elisabeth in Spanje bezocht. Koning Filips leed aan serieuze depressies en koningin Elisabeth merkte dat Farinelli 's zang een heilzame werking uitoefende op de koning. Zij bood hem een levenslang contract met een vorstelijk honorarium aan en vervolgens bleef Farinelli inderdaad zijn hele verdere leven verbonden aan het Spaanse hof en zong iedere dag voor de koning.

Een castraat als depressie therapie: dat is nog eens een mooi voorbeeld van personalized medicine. Precisie-geneeskunde gaat uit van het principe dat iedere behandeling gebaseerd dient te zijn op de persoonlijke kenmerken van een individu. Dit klinkt als een open deur, maar het is toch een vernieuwing ten opzichte van de huidige praktijk van de evidence- based medicine. In de evidence-based-farmacotherapie is de gerandomiseerde klinische trial de standaard aanpak. Het geneesmiddel wordt getest in een zo groot mogelijke, breed samengestelde groep patiënten. Als de gemiddelde effectiviteit van het geneesmiddel groter is dan die van het placebo in de identiek samengestelde controlegroep spreken we over een effectief geneesmiddel. We hebben het dan echter over een gemiddelde patiënt. Een gemiddeld mens beschikt over één teelbal en één borst. In werkelijkheid hebben echter de meeste mensen óf twee teelballen óf twee borsten. "Personalized" of "precisie" geneeskunde probeert de therapie te baseren op zulke individuele kenmerken.

Terug naar de depressie. Depressie is een moeilijk behandelbare aandoening. De één vaart wel bij een zingende castraat of bij de vrolijke deuntjes van M umford\&Sons, sommige vinden hun heil in mindfullness of hardlopen, en weer anderen genezen dankzij de hulp van een geduldige psychiater uit de school van de "Verstehende" psychiatrie van iemand als oud-collega M ark Richartz (figuur 16). M et collega Richartz heb ik jarenlang het blok "Hoofdzaken 
en Kopzorgen" als inleiding op de psychiatrie voor derde jaar studenten verzorgd. Mark Richartz koos voor de ets "El sueno de razón produce monstruos" van Goya - waarvan hij zelf een origineel exemplaar bezat - als omslag voor het blokboek (figuur 17). Samen gaven wij het openingscollege van dat blok, waarbij Mark meestal 1 uur 50 minuten van de beschikbare 2 uur gebruikte. Ik heb daar nooit enig bezwaar tegen gemaakt, want Mark was een boeiende en erudiete collegegever. Hij leerde mij - en de derde jaars - een belangrijke les door uit te leggen dat "el sueno de razón" vertaald kan worden als de "slaap", maar ook als de "droom" van de rede: twee nogal verschillende duidingen. Een bondiger uitleg van de bron van het onbehagen in de cultuur heb ik nooit gehoord.
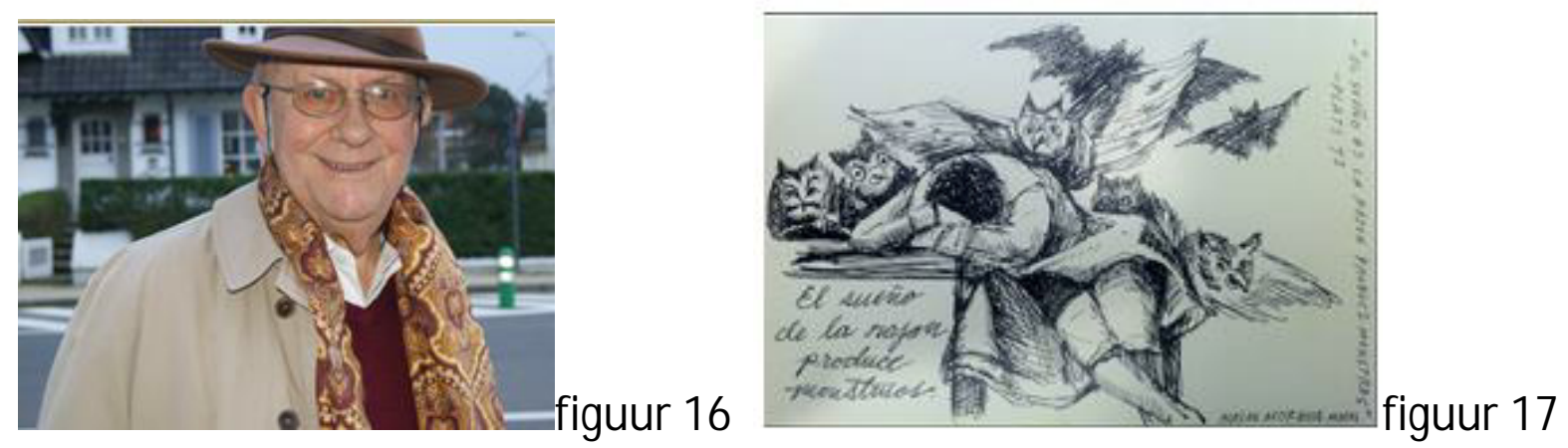

De rol van antidepressiva in de behandeling van depressies is een onderwerp van veel discussie in de afgelopen jaren. Recent hebben Vinkers en Vis in hun boek "Even slikken" (15) deze discussie goed samengevat. Het leidt geen twijfel dat antidepressiva bij sommige mensen een stemmingsverbeterende werking hebben. Hierbij is echter ook sprake van een relatief groot placebo effect. In Nederland slikken meer dan 1 miljoen mensen antidepressiva en uit een recent Amerikaans onderzoek blijkt dat in de Verenigde Staten zelfs meer dan 1 op de 5 vrouwen boven de 40 jaar antidepressiva slikt (16; figuur 18), waarvan meer dan twee derde langer dan 2 jaar (figuur 19). Toch is het aantal mensen dat daadwerkelijk aan een depressie lijdt waarvoor een langdurige therapie met een antidepressivum noodzakelijk is, aanzienlijk lager. Sommige mensen slikken antidepressiva om andere redenen of - veel waarschijnlijker - omdat ze verslaafd zijn geraakt in een periode van depressie en de middelen nog steeds doorslikken. De term verslaafd is hier farmacologisch niet helemaal correct, de juiste term is afhankelijkheid, d.w.z. dat het moeilijk is om te stoppen met een eenmaal gestarte therapie met antidepressiva (17). Hetzelfde geldt voor middelen tegen angst- of slaapstoornissen, zoals benzodiazepines. Ten 
onrechte worden de onttrekkingsverschijnselen vaak geïnterpreteerd als een terugkeer van de angst of depressie. In feite is er sprake van een verstoord evenwicht in een aantal lichamelijke en psychische functies.

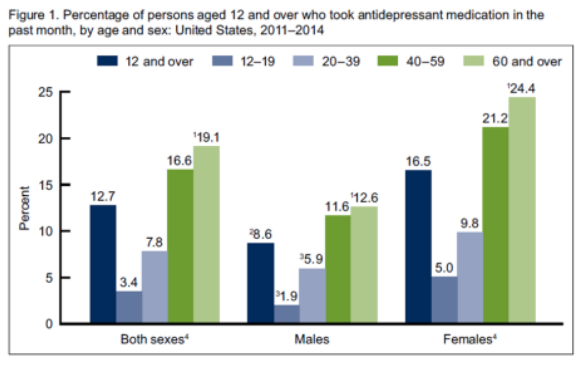

NCHS Data Brief No. 283 August 2017 figuur 18

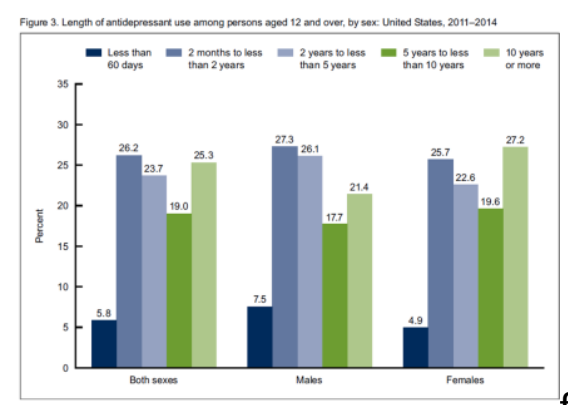

figuur 19

Op het punt van de psychofarmaca past de farmacoloog absoluut geen triomfantelijk gedrag, maar is bescheidenheid op zijn plaats. Ook huisartsen en psychiaters zijn zich mijns inziens onvoldoende bewust van de risico's van langdurig gebruik van psychofarmaca en met name van de afhankelijkheid die deze middelen veroorzaken. Ook Vinkers en Vis besteden aan dit punt in hun overigens zeer volledige boek te weinig aandacht. Abrupt stoppen met psychofarmaca kan tot gevaarlijke, soms levensbedreigende situaties leiden. Geleidelijke, gecontroleerde afbouw is de te prefereren methode, maar wordt vaak niet gevolgd door patiënten en hun behandelaars. Mijns inziens heeft het moderne neurodeterminisme van populair -wetenschappelijke schrijvers van boeken met titels als "Wij zijn ons brein" een funeste invloed op een verantwoorde psychofarmacotherapie. Depressie heeft een bij uitstek persoonlijke ziektegeschiedenis die niet in een kort diagnostisch gesprek valt samen te vatten met het concept "tekort aan serotonine", zoals sommige neurodeterministen ons willen doen geloven.

In zijn bescheidenheid dient de farmacoloog zich te ontwikkelen tot een precisie-heelmeester. De precisie-geneeskunde wordt op dit moment het sterkst ontwikkeld op het gebied van de kankerbehandeling (18). De kern van de precisie behandeling van kanker is dat van iedere individuele kankerpatiënt de moleculaire kenmerken van de tumor worden bepaald. Vervolgens wordt een geneesmiddel gekozen dat specifiek aangrijpt op die moleculaire tumorkenmerken. Een kostbare, maar wel heel precieze behandeling. Deze benadering is in de kankerbehandeling succesvol, omdat kanker een tot op moleculair niveau herleidbare ziekte is. Dit is helaas niet het geval voor de 
meeste hart- en vaatziekten of psychiatrische aandoeningen als depressie of angststoornissen. Hoge bloeddruk en depressie zijn wat men in de systeemtheorie noemt emergente verschijnselen op een hoger integratieniveau dan het moleculaire. De precisie-farmacoloog zal daartoe ten nauwste moeten samenwerken met de clinicus die in staat is via precisiediagnostiek op meerdere niveaus en een systeem-analytische aanpak een nauwkeurig beeld van de patiënt te schetsen.

Dit brengt mij op het laatste deel van deze rede: het onderwijs in de farmacologie. Hoewel deze rede vooral over onderzoek en ontmoetingen ging, heb ik altijd veel belang gehecht aan het farmacologie onderwijs. Mijn favoriete onderwijsvorm hierbij was de farmacotherapie bespreking in de co-schappen fase. In groepjes van 10-20 studenten bespraken wij daarin diepgaand farmacotherapeutische vraagstukken die studenten in hun praktijk tegenkwamen. Zulke besprekingen zijn alleen effectief als de studenten over de nodige basiskennis over geneesmiddelen beschikken. Als arts besteden ze later namelijk circa 30\% van hun tijd aan therapie-gerelateerde onderwerpen. De precisie-geneeskunde stelt nog veel hogere eisen aan de farmacologische kennis van toekomstige artsen. En hetzelfde geldt voor de eerder genoemde veiligheidseisen van het verantwoord gebruik van geneesmiddelen. Collega Leufkens uit Utrecht vergeleek onlangs bij zijn afscheid als voorzitter van de Commissie ter Beoordeling van Geneesmiddelen de moderne geneesmiddelen met een Ferrari. Prachtige auto, maar je moet er wel in kunnen rijden. Wij geven artsen en patiënten deze Ferrari's ter beschikking zonder dat onze jonge artsen een rijexamen hoeven af te leggen. Nederlandse farmacologen pleiten al jaren voor een Geneesmiddel veiligheidsexamen als onderdeel van de medische opleiding. Sommige faculteiten hebben zo'n examen inderdaad ingevoerd. De M aastrichtse onderwijsorganisatie wijst zo'n examen tot nu toe af op grond van onderwijskundige argumenten. Ik vrees dat die onderwijsorganisatie te ver af staat van de medische praktijk. Zelfs Max Verstappen moet rijexamen doen om in een Ferrari aan het Nederlands wegverkeer deel te nemen.

Ik kom aan het einde van mijn rede, waarin ik nog enkelen wil danken die ik niet eerder noemde. Op de eerste plaats zijn dat de talrijke bestuurders met 
wie ik aan deze universiteit de laatste 42 jaar te maken heb gehad. Steeds -of bijna steeds- hebt U mijn keuzes gesteund of zelfs geïnspireerd, waarvoor dank.

Een speciaal woord van dank aan oud-decaan Harry Hillen voor zijn rotsvaste vertrouwen in de menselijke veerkracht.

Het CARIM team, onder leiding van de onvolprezen Rob van der Zander heeft al vanaf de oprichting in 1987 het CARIM schip op koers gehouden.

De medewerkers en oud-medewerkers van de vakgroep Farmacologie en Toxicologie ben ik zeer dankbaar voor hun inzet, vriendschap en vertrouwen in goede en slechte tijden. Ans Lippinkhof, Els Geurts, Mia Hogenboom, Josephina Walthouwer en M arie-Claire van der Voort waren en zijn rotsen in de branding op het secretariaat van de vakgroep. Aalt Bast heeft de vakgroep de laatste jaren in een moeilijke periode kundig geleid, mede dankzij zijn unieke kennis van zowel de farmacologie als de toxicologie.

Onze vakgroep heeft in de loop der jaren meer dan 100 promovendi en postdocs opgeleid tot farmacoloog of toxicoloog. 17 Van jullie zijn inmiddels zelf hoogleraar, maar ik ben even trots op al degenen die als medisch specialist of in het onderwijs, de industrie, de overheid of als Z.Z.P'er terecht zijn gekomen. Het was een groot voorrecht om jullie in de laatste fase van jullie vormende jaren te hebben mogen begeleiden.

Het zijn niet alleen de schouders van reuzen die nieuwe perspectieven bieden. Ik heb het geluk gehad in diverse fases van mijn leven langdurige vriendschappen te hebben gekend. Ik ben die vrienden en vriendinnen dankbaar voor die ontmoetingen.

En dan tenslotte het thuisfront, zonder Ardi, zoals aangekondigd.

Vivian, al een paar jaar voeg jij veel vrolijke, vrouwelijke vriendschap toe aan ons mannengezin.

Samuel en Ramses, mannen: jullie geleidelijk te zien worden wie jullie zijn is veruit de meest dierbare ervaring op mijn levenspad. Het laatste woord is niet alleen vóór jullie, maar vooral áán jullie.

Ik heb gezegd. 


\section{REFERENTIES}

1. Safranski R. Goethe: Kunstwerk des Lebens. Hanser, Deutschland, 2014.

2. Borges JL. De essays. De Bezige Bij, 2016.

3. Harari YN. Homo Deus: een kleine geschiedenis van de toekomst. Thomas Rap, 2017.

4. M ishra P. Age of Anger: a history of the present. Allen Lane, UK 2017.

5. Struijker-Boudier H. and Van Rossum JM. Dopamine-induced inhibition and excitation of neurones of the snail Helix aspersa. Arch Int Pharmacodyn 209, 314-324, 1974.

6. Guyton AC, Coleman TG, Cowley AR et al. Systems analysis of arterial pressure regulation and hypertension. Ann Biomed Eng 1, 254-281, 1972.

7. Struijker-Boudier H, Heilmann K, Urquhart J. Risiko's meten: een antwoord op de angst voor een technologische kultuur. Anthos, 1985.

8. Mensah GA, Wei GS, Sorlie PD et al. Decline in cardiovascular mortality: possible causes and implications. Circ Res 120, 366-380, 2017.

9. Burnier M, Wuerzner G, Struijker-Boudier H, Urquhart J. M easuring, analyzing, and managing drug adherence in resistant hypertension. Hypertension 62, 218 - 225, 2013.

10.Leendertse A. Hospital admissions related to medications. Ph.D. thesis, Utrecht University, 2010.

11. Derrida J. Plato's Pharmacy. Tel Quel nos 32 et 33, 1968.

12.Girard R. Le bouc émissaire. Grasset, France 1982.

13. Céline LF. La vie et l'oeuvre de Philippe Ignace Semmelweis. Editions Gallimard, France 1977.

14.Gu YM, Struijker-Boudier H, Staessen JA et al. Characteristics and determinants of the sublingual microcirculation in populations of different ethnicity. Hypertension 65, 993-1001, 2015.

15.Vinkers C, Vis R. Even slikken: de zin en onzin van antidepressiva. Prometheus, 2017.

16.Pratt LA, Brody DJ, Gu Q. Antidepressant use among persons aged 12 and over: United States, 2011-2014. NCHS Data Brief no. 283, 2017. 
17.Fava GA, Gatti A, Belaise $C$ et al. Withdrawal symptoms after selective serotonin reuptake inhibitor discontinuation: a systematic review. Psychother Psychosom 84, 72-81, 2015.

18.Borad MJ, LoRusso PM. Twenty-first century precision medicine in oncology: genomic profiling in patients with cancer. Mayo Clin Proc. 92, 1583-1591, 2017. 